\title{
EGFR NP_005219.2:p.A763_Y764insFQEA
}

National Cancer Institute

\section{Source}

National Cancer Institute. EGFR NP 005219.2:p.A763 Y764insFQEA. NCI Thesaurus.

Code C98611.

An insertion of the amino acid sequence phenylalanine-glutamine-glutamic acid-alanine between the alanine at position 763 and the tyrosine at position 764 of the epidermal growth factor receptor protein. 